\title{
MORPHOLOGICAL CHARACTERIZATION AND CLASSIFICATION OF CASSAVA (Manihot esculenta Crantz) IN VIETNAM
}

\author{
Chu Duc Ha ${ }^{1}$, Le Thi Ngoc Quynh ${ }^{1}$, Nguyen Trong Hien ${ }^{2}$, \\ Pham Thi Ly Thu ${ }^{1}$, Le Huy Ham ${ }^{1}$, Le Tien Dung ${ }^{1}$ * \\ ${ }^{1}$ International Laboratory for Cassava Molecular Breeding (ILCMB), Agricultural Genetics Institute \\ ${ }^{2}$ Root Crop Research and Development Center, Field Crops Research Institute
}

\begin{abstract}
The aim of this study was to establish the morphological basis for the classification of major cassava cultivars (Manihot esculenta Crantz) planted in Vietnam. Twenty typical descriptors were observed in various specific growth stages. Four traits related to mature leaves and two traits related to leaf veins were detected in cassava plants after the 4-month stage. At the same time, 12 root- and stem- related descriptors were collected in cassava plants from 8 months old to harvest. We found that two traits in the apical leaves can be observed in every growth stage. A classification tree based on these traits was constructed with 6 essential morphological descriptors to recognize the 7 most common cassava cultivars in Vietnam. KM 140 variety is distinguished by purplish-red in apical leaves, while KM 98-7 can be classified with straight or linear shapes of central leaflet. The irregular orientation of the petiole is a unique descriptor of local cultivar XVP. In the case of SM 937-26, weak foliar scars are observed. Finally, KM 94, KM 419, and KM 98-5 varieties can be classified by the color of the stem epidermis. These morphological descriptors will be a foundation to classify all cassava varieties planted in Vietnam.
\end{abstract}

Keywords: Manihot esculenta, cassava plant, morphology, growth stage, phenotype, descriptors

Citation: Chu Duc Ha, Le Thi Ngoc Quynh, Nguyen Trong Hien, Pham Thi Ly Thu, Le Huy Ham, Le Tien Dung, 2016. Morphological characterization and classification of cassava (Manihot esculenta Crantz) in Vietnam. Tap chi Sinh hoc, 38(3): 344-351. DOI: 10.15625/0866-7160/v38n3.8570.

*Corresponding author: research@letiendung.info.

\section{INTRODUCTION}

Cassava (Manihot esculenta Crantz), an annual food crop in the tropical regions, is one of the most important crops of the Euphorbiaceae family. It is mainly grown in Africa, the Caribbean, and Asia [5]. Having high concentration of carbohydrates and being easy to grow, cassava is regarded as a multifunctional plant, such as food, feed, and raw materials in various industries. Thus, this tuber crop is not only a poor man's food but also a cash crop for millions of people living in rural areas of Southeast Asia, including Vietnam [9].

Cassava varieties have been distinguished from one another by morphological descriptors observed in major organs, such as leaves, stems and roots. Unfortunately, a number of phenotypical characters can change significantly depending on the cultural practice and the pressure of abiotic and/or biotic stresses $[11,13]$, making germplasm characterization, conservation and breeding systems more difficult. In Vietnam, a comprehensive study of phenotypic characterization is still lacking [7, 8]. Thus, a list of morphological descriptors has not yet been established for the DUS (Distinctness, Uniformity and Stability) and VCU (Value for Cultivation and Use) trials.

Therefore, the objective of this study is to establish a set of morphological descriptors that are typical and specific for growth stages of cassava plants, and to initially construct the phenotype-based classification chart of cassava varieties in Vietnam. This work may provide a significant lead for further studies seeking to establish a complete characterization of cassava in Vietnam.

\section{MATERIALS AND METHODS}

Seven cassava varieties $[10,16]$, including 5 of the most cultivated varieties, 1 promising new variety, and 1 local variety were obtained 
from the field of the Root Crop Research and Development Center (RCRDC), Field Crops Research Institute, located in Chuong My, Hanoi as described in table 1.

The morphological descriptors used in this study were based on the reference list of morphologies selected by the International Institute of Tropical Agriculture (IITA) [6] and the draft guidelines for conducting tests for distinctness, uniformity and stability, published by the International Union for the Protection of New Varieties of Plants (UPOV). The experiments were conducted from October 2014 to April 2015. Observations were carried out with 3 replicates. All photos and the classification tree were subsequently visualized using Adobe Illustrator.

Table 1. Seven cultivated cassava varieties in Vietnam used in this study

\begin{tabular}{|c|c|c|c|c|}
\hline No & Name & Origin & Pedigrees & Year released \\
\hline 1 & $\begin{array}{l}\text { KM } 94 \\
\text { (KU 50/ Kasetsart 50/ } \\
\text { MTAI16/MKUC 29-77-3) }\end{array}$ & Kasetsart/Thailand & $\begin{array}{l}\text { Rayong } 1 \times \\
\text { Rayong } 90\end{array}$ & $\begin{array}{l}\text { Released in Vietnam } \\
\text { in } 1995 \text { [15] }\end{array}$ \\
\hline 2 & SM 937-26 (SM 937) & CIAT/Colombia & Unknown & $\begin{array}{l}\text { Released in Vietnam } \\
\text { in } 1995 \text { [15] }\end{array}$ \\
\hline 3 & KM 98-5 & IAS/Vietnam & $\begin{array}{l}\text { KM 98-1 } \times \\
\text { Rayong } 90\end{array}$ & Unknown \\
\hline 4 & KM 98-7 (SM17-17-12) & RFCRC/Thailand & $\begin{array}{l}\text { SM } 17-17 \times C M \\
321-188\end{array}$ & Unknown \\
\hline 5 & KM 140 & IAS/Vietnam & $\begin{array}{l}\text { KM } 36 \times \mathrm{KM} \\
98-1\end{array}$ & Unknown \\
\hline 6 & KM 419 (SVN5) & Unknown & $\begin{array}{l}\text { BKA } 900 \times \\
(\text { KM } 98-5 \times \text { KM } \\
98-5)\end{array}$ & Unknown \\
\hline 7 & XVP ("Xanh Vinh Phu") & Local variety & Unknown & Unknown \\
\hline
\end{tabular}

CIAT: International Center for Tropical Agriculture; IAS: Institute of Agricultural Sciences for Southern Vietnam; RFCRC: Rayong Field Crop Research Center.

\section{RESULTS AND DISCUSSION}

Typical morphological characteristics of cassava at various development stages

Based on two standard characterization systems released by UPOV and IITA [6], five most vital organs - apical leave, mature leave, petiole, stem and root - were screened to obtain descriptors that are easy to collect in the fields. This screening was based on the observations conducted by CIAT and the Brazilian Agricultural Research Corporation (EMBRAPA, Brazil) and can be applied to the world's main cassava collections [6]. In this study, we found 20 morphological characteristics in those 5 organs: 4 of those were identified in mature leaves, while 2 and 7 descriptors were recognized in petioles and stems, respectively. There were 5 descriptors in roots, and 2 traits recorded in apical leaves. A list of 20 morphological descriptors for characterization of cassava used in this study was established previously and shown in table 2. The scales of 20 descriptors were established and developed based on previously described $[6,7]$, while code of each descriptor was used as mentioned in previous report [4].

It should be noted that three distinct tissues comprise a mature cassava root. Care should be taken to correctly separate the tissues for correct characterization of the root pulp and root cortex colors. The root pulp, known as "parenchyma", is composed of xylem vessels radially distributed in a complex of starch-containing cells [17]. The root cortex, composed of sclerenchyma, cortical parenchyma and phloem, is a thin layer of cells on the outermost part of 
the root [14]. Thus, the manual removal of the root cortex from the middle third of freshly harvested root tuber is recommended to observe the color of this peel layer, while a cross-section of mature cassava root was used to obtain the color of parenchyma tissues.

Table 2. List of typical morphological descriptors for characterization of cassava used in this study

\begin{tabular}{|c|c|c|c|c|}
\hline Growth stage & Organ & Descriptor & CODE & Scale \\
\hline \multirow[t]{6}{*}{ After 4 months } & \multirow[t]{4}{*}{ Mature leaf } & Shape of central leaflet & FFAD $^{1}$ & $\begin{array}{l}\text { Ovoid } \\
\text { Elliptic } \\
\text { Linear } \\
\text { Lanceolate } \\
\text { Pandurate } \\
\text { Obovate }\end{array}$ \\
\hline & & Leaf color & CLAD $^{1}$ & $\begin{array}{l}\text { Light green } \\
\text { Dark green } \\
\text { Purplish green } \\
\text { Purplish red } \\
\end{array}$ \\
\hline & & Number of leaf lobes & $\mathrm{NLB}^{2}$ & $3 / 5 / 7 / 9 / 11$ lobes \\
\hline & & Color of leaf vein & $\mathrm{CNFE}^{\mathrm{I}}$ & $\begin{array}{l}\text { Green } \\
\text { Reddish green } \\
\text { Red } \\
\text { Purple }\end{array}$ \\
\hline & \multirow[t]{2}{*}{ Petiole } & Petiole color & CPET $^{1}$ & $\begin{array}{l}\text { Yellowish green } \\
\text { Green } \\
\text { Reddish green } \\
\text { Greenish red } \\
\text { Red } \\
\text { Purple }\end{array}$ \\
\hline & & Orientation of petiole & $\mathrm{OP}^{2}$ & $\begin{array}{l}\text { Semi-erect } \\
\text { Horizontal } \\
\text { Dropping } \\
\text { Irregular }\end{array}$ \\
\hline \multirow[t]{5}{*}{ After 8 months } & \multirow[t]{5}{*}{ Stem } & $\begin{array}{l}\text { Prominence of foliar } \\
\text { scars }\end{array}$ & $\mathrm{PFS}^{2}$ & $\begin{array}{l}\text { Weak }(0-3 \mathrm{~mm}) \\
\text { Medium }(4-8 \mathrm{~mm}) \\
\text { Strong }(\geq 8 \mathrm{~mm})\end{array}$ \\
\hline & & Color of stem exterior & CTIG $^{1}$ & $\begin{array}{l}\text { Orange } \\
\text { Grayish yellow } \\
\text { Green } \\
\text { Greenish yellow } \\
\text { Brownish yellow } \\
\text { Light brown } \\
\text { Dark brown } \\
\text { Grey }\end{array}$ \\
\hline & & Color of stem epidermis & $\mathrm{CSE}^{2}$ & $\begin{array}{l}\text { Cream } \\
\text { Light brown } \\
\text { Dark brown } \\
\text { Orange } \\
\text { Purple } \\
\end{array}$ \\
\hline & & Color of stem cortex & $\mathrm{CSC}^{2}$ & $\begin{array}{l}\text { Light green } \\
\text { Dark green } \\
\text { Orange } \\
\text { Cream } \\
\text { Purplish } \\
\end{array}$ \\
\hline & & Growth habit of stem & $\mathrm{GHS}^{2}$ & Straight \\
\hline
\end{tabular}


Chu Duc Ha et al.

\begin{tabular}{|c|c|c|c|c|}
\hline & & & & Zigzag \\
\hline \multirow[t]{8}{*}{ Harvest } & \multirow[t]{2}{*}{ Stem } & Level of branching & PORT $^{1}$ & $\begin{array}{l}\text { Unbranched } \\
\text { Branched }\end{array}$ \\
\hline & & Shape of plant & $\mathrm{SP}^{2}$ & $\begin{array}{l}\text { Compact } \\
\text { Open } \\
\text { Umbrella } \\
\text { Cylindrical }\end{array}$ \\
\hline & \multirow[t]{6}{*}{ Root } & Extent of root peduncle & LPED $^{1}$ & $\begin{array}{l}\text { Absent } \\
\text { Present }\end{array}$ \\
\hline & & Root shape & FRTU $^{1}$ & $\begin{array}{l}\text { Conical } \\
\text { Conical to Cylindrical } \\
\text { Cylindrical } \\
\text { Irregular }\end{array}$ \\
\hline & & $\begin{array}{l}\text { External color of storage } \\
\text { root }\end{array}$ & $\mathrm{CEPI}^{\top}$ & $\begin{array}{l}\text { Cream } \\
\text { Light brown } \\
\text { Dark brown }\end{array}$ \\
\hline & & $\begin{array}{l}\text { Color of root pulp } \\
\text { (parenchyma) }\end{array}$ & $\mathrm{CCHA}^{1}$ & $\begin{array}{l}\text { White } \\
\text { Cream }\end{array}$ \\
\hline & & & & $\begin{array}{l}\text { Light yellow } \\
\text { Dark yellow } \\
\text { Pink }\end{array}$ \\
\hline & & $\begin{array}{l}\text { Color of root cortex } \\
\text { (peel) }\end{array}$ & $\mathrm{CPHE}^{1}$ & $\begin{array}{l}\text { White } \\
\text { Cream } \\
\text { Yellow } \\
\text { Pink } \\
\text { Purple } \\
\end{array}$ \\
\hline \multirow[t]{2}{*}{ Any stages } & \multirow[t]{2}{*}{ Apical leaf } & Color of apical leaves & CAPE $^{1}$ & $\begin{array}{l}\text { Light green } \\
\text { Dark green } \\
\text { Purplish green } \\
\text { Purple }\end{array}$ \\
\hline & & $\begin{array}{l}\text { Pubescence on apical } \\
\text { leaves }\end{array}$ & $\mathrm{PAL}^{2}$ & $\begin{array}{l}\text { Absent } \\
\text { Present }\end{array}$ \\
\hline
\end{tabular}

${ }^{1}$ According to Boni et al., 2014; ${ }^{2}$ Encoded as abbreviation of first symbol.

To be able to characterize cassava plants in the fields accurately, we separately arranged 20 morphology observations in 4 major growth stages (table 2). Four months after planting, we can observe all descriptors in the mature leaves and petioles. From 9 months to harvest stage, the growth habit, colors of 3 components of stem and the prominence of the foliar scars became distinct enough for analyzing the stem of cassava plants. During the harvest period, 2 traits in the stems and all traits in the commercial roots were observable. The time point and duration of each developmental phase depend on varietal characteristics, environmental conditions and the cultural practice. Apical leaf observations may be recorded in any growth stages of plants (table 2).

Our data were compared with that of previous studies to propose a list of descriptors that are deemed essential and reliable in phenotypical characterization of cassava. Afonso recently reported an experiment to characterize 200 accessions from EMBRAPA's Cassava Germplasm Active Bank (BAGM, Brazil) using 35 morphological and agronomic descriptors [1]. Importantly, 20 characters are found to be important in the classification of germplasm of manioc, eleven of those being quantitative descriptors and nine qualitative. To evaluate and improve the precision of the description, Antonio found 14 stable and discriminating descriptors of botanical and agronomical characteristics, including 5 used in this study, to characterize the 280 cassava accessions in BAGM [3]. A number of those traits related to the mature leave, stem, 
or the root - such as length/width of the leaf lobe, plant height, easiness of root periderm removal, respectively - were altered drastically under various environmental conditions [2, 11, 12, 13]. In the effort to characterize a total of 159 traditional varieties in Côte d'Ivoire, 14 important characteristics of leave, stem, tuberous root, and other organs were reported [4].
All 20 of the morphological descriptors used in this study are typical and representative of the 4 growth stages. They are also specific and do not change significantly under environment variations.

Construction of a classification chart of major cassava cultivars in Vietnam

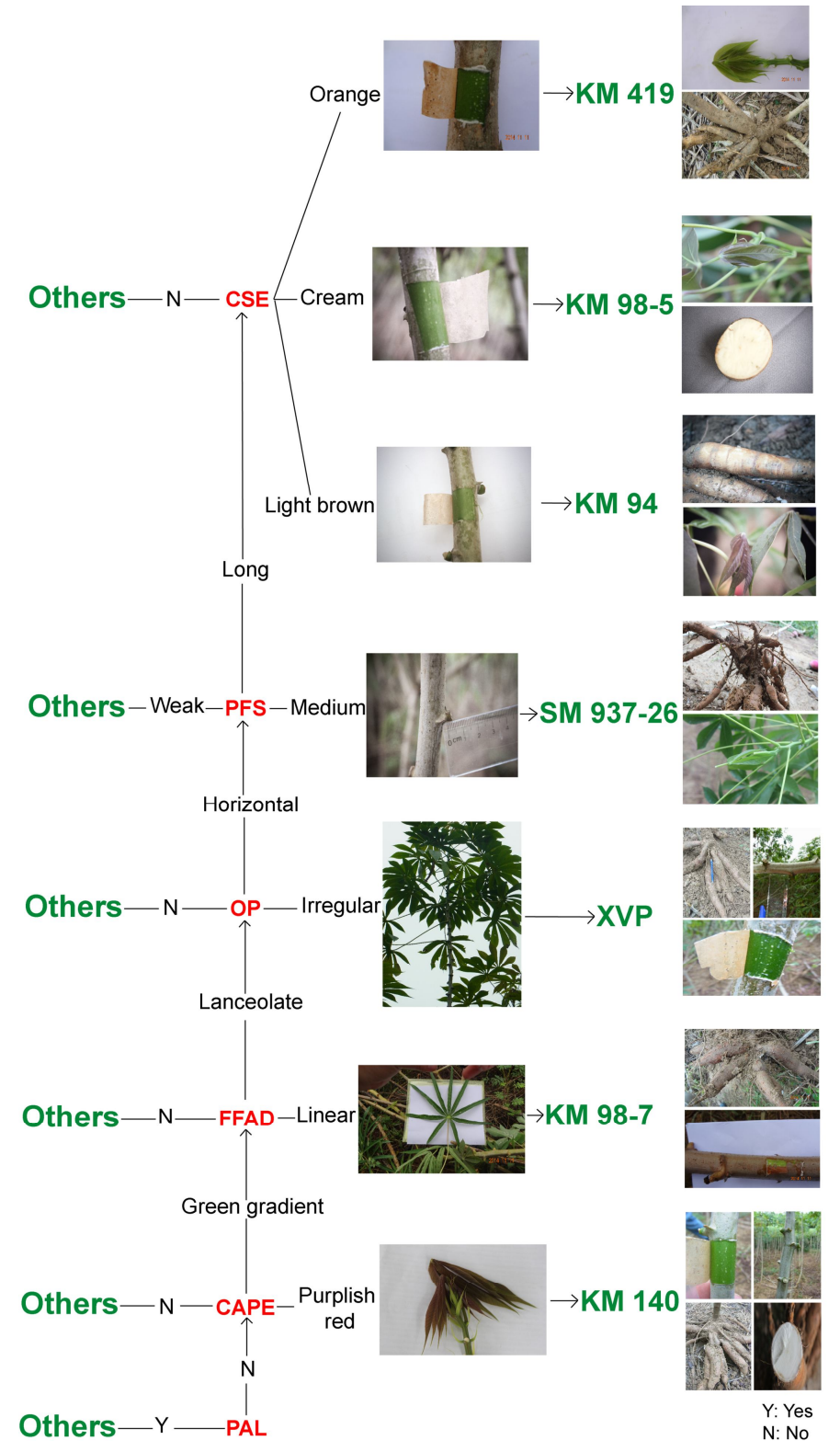

Figure 1. Morphology-based characterization chart of cassava varieties in Vietnam

PAL: Pubescence on apical leaves; CAPE: Color of apical leaves; FFAD: Shape of central leaflet; OP: Orientation of petiole; PFS: Prominence of foliar scars; CSE: Color of stem epidermis. 
To classify the most cultivated cassava varieties in Vietnam, we constructed a characterization chart based on phenotypical observations. In this study, we used 6 most discriminating descriptors as the nodes in a chart characterizing 7 cassava varieties in Vietnam, including (i) pubescence on apical leaves (PAL), (ii) color of apical leaves (CAPE), (iii) shape of central leaflet (FFAD), (iv) orientation of petiole (OP), (v) prominence of foliar scars (PFS), and (vi) color of stem epidermis (CSE). In this proposed chart, we minimized the scale of color descriptors to reduce the errors of color observations in the field, as caused by different light conditions and/or photography techniques. For example, the color of apical leaves might be recorded as 2 contrasting colors: green gradient (including light/dark/purplish-green) and purple. Together, the characterization chart was built as figure 1 .

As a result, 7 cassava varieties in Vietnam were recognized individually by using the 6 descriptors mentioned above. Firstly, KM 140 was classified initially by the purplish-red color recorded in the CAPE at every growth stage. In the case of the 6 varieties sharing the green gradient of apical leaves, the FFAD was used to distinguish the KM 98-7 variety, whose central leaflet is almost linear. Next, XVP, a local variety, can be characterized by the irregular orientation of its petiole. SM 937-26 was then observed as following the typical medium foliar scar (commonly 4-8 mm). Finally, 3 remaining cassava varieties, KM 94, KM 98-5 and KM 419 were classified by different colors of stem epidermis. The stem epidermis of KM 94 and KM 98-5 were light brown and cream, respectively, with the epidermis of KM 419 being orange. All cases of different observations in other varieties are mentioned on the left side of the chart.

The phenotypic characterization of 7 cassava varieties in Vietnam using 6 morphological descriptors by the classification chart is straightforward. To further compare cassava varieties - not only those most cultivated in Vietnam but also popular in other parts of Asia (Thailand, Cambodia, China, etc) additional phenotypical descriptors should be used [18]. Thus, the classification chart must be more detailed to adapt to further characterization of cassava germplasm.

\section{CONCLUSION}

Twenty typical morphological descriptors specific to four growth stages were used to characterize cassava varieties in Vietnam. Initial results on the classification of seven cassava varieties in Vietnam indicated that KM 140 variety can be identified by the purplish-red color in apical leaves at every stage of growth, while KM 98-7 variety can be classified by the linear shape of central leaflet. Irregular petiole orientation is a descriptor unique to the local cultivar, XVP. In the case of SM 937-26, observation of weak foliar scars was recorded. Finally, KM 94, KM 419, and KM 98-5 varieties can be classified by the color of stem epidermis.

Acknowledgements: This study was a part of the training "On-the-job research capacity building for sustainable agriculture in developing countries" funded by the Japan Ministry of Agriculture, Forestry and Fisheries (MAFF) and managed by the United Nations University Institute of Advance Studies (UNUIAS). The authors would like to thank Dr. Manabu Ishitani (CIAT) for his contribution as a technical consultant. Research in DTL group at AGI was funded by the National Foundation for Science and Technology Development of Vietnam under the grant number 106-NN.022013.46. Equipment at the International Laboratory for Cassava Molecular Breeding (ILCMB) was funded by the CGIAR-RTB program to CIAT and its partners in 2014. The authors wish to thank Stephanie K. Dalquist (skd@mit.edu) for improving English usage in this manuscript.

\section{REFERENCES}

1. Afonso S. D., Ledo C. A., Moreire R. F., Silva S., Leal V. D., Conceicao A. L., 2014. Selection of descriptors in a morphological characteristics considered in cassava accessions by means of multivariate techniques. Journal of Agriculture and Veterinary Science, 7(1): 13-20. 
2. Alves A. C., Setter T. L., 2004. Response of cassava leaf area expansion to water deficit: Cell proliferation, cell expansion and delayed development. Annual of Botany, 94(4): 605-613.

3. Antonio V. P., Roland V., Cosme D. C., 1992. Selection of botanical and agronomical descriptors for the characterization of cassava (Manihot esculenta Crantz.) germplasm. Brazil Journal of Genetics, 15(1): 115-124.

4. Boni N., Okoma M. P., Kouakou A. M., Dibi K. E. B., Zohouri G. P., Essis B. S., Dansi A. A., 2012. Morphological characterization of cassava (Manihot esculenta Crantz.) accessions collected in the Centre-west, South-west and West of Cote d'Ivoire. Greener Journal of Agricultural Sciences, 4(6): 220-231.

5. Ceballos H., Iglesias C. A., Pérez J. C., Dixon A. G. O., 2004. Cassava breeding: opportunities and challenges. Plant molecular biology, 56(4): 503-516.

6. Fukuda W. M. G, Guevara C. L., Kawuki R., and Ferguson M. E., 2010. Selected morphological and agronomic descriptors for the characterization of cassava. International Institute of Tropical Agriculture, Research Nourish Africa, 28 pp.

7. Chu Duc Ha, Le Thi Ngoc Quynh, Nguyen Trong Hien, Le Huy Ham, Le Tien Dung, 2015. Identification of morphological descriptors for characterization of cassava (Manihot esculenta Crantz.) in Vietnam based on KM 94 variety. Tap chi Sinh hoc, 37(1): 31-38 (in Vietnamese).

8. Hang T. T. N., Nga T. H., Hoa T. T., Ha P. N., 2012. Results of evaluation of cassava germplasm in Vietnam: Period 2010-2011. Scientific Reports. Vietnam Plant Resources Center (in Vietnamese), 6 pp.

9. Howeler R. H., 2014. Sustainable soil and Crop management of Cassava in Asia. A reference manual. CIAT Publication No. 389, ISBN 978-958-694-125-9.

10. Howeler R. H., Kawano K., Ceballos H.,
2006. CIAT initiatives on cassava improvement in ASIA. In: souvenir $14^{\text {th }}$ triennial symposium of the international society for tropical root crops. Central Tuber Crops Research Institute, Trivandrum, India: 25 - 31 .

11. Kawano K., Fukuda W. M. G., Cenpukdee U., 1987. Genetic and environmental effects on dry matter content of cassava root. Crop Science, 27(1): 69-74.

12. Lenis J. I., Calle F., Jaramillo G., Perez J. C., Ceballos H., Cock J. H., 2006. Leaf retention and cassava productivity. Field Crops Research, 95(2-3): 126-134.

13. Olasantan F. O., Ezumah H. C., Lucas E. O., 1997. Response of cassava and maize to fertilizer application, and a comparison of the factors affecting their growth during intercropping. Nutrient Cycling in Agro ecosystems, 46(3): 215-223.

14. O'Hair S. K., (1990). Tropical Root and Tuber Crops. In: J. Janick and J.E. Simon (eds.), Advances in new crops. Timber Press, Portland, 424-428

15. Quyen N. T., Kim H., Tuan V. V., Kwano K., 1995. New cassava varieties with high starch. Conference on Agricultural Science and Technology in Southern Vietnam, MARD, 26pp (in Vietnamese).

16. Robinson J., Srinivasan C. S., 2013. Casestudies on the impact of germplasm collection, conservation, characterization and evaluation (GCCCE) in the CGIAR. The Consultative Group for International Agricultural Research Publications, 41pp.

17. Wheatley C. C., Chuzel G., 1993. Cassava: the nature of tuber and use as a raw material. In: Macrae R., Robinson R. K., Sadler M. J., (eds) Encyclopedia of food science food technology, and nutrition. Academic press, San Diego, California, 734-743.

18. Wongtiem P., 2013. Characterization of cassava germplasm in Thailand. Report of the Rayong Field Crops Research Center. Department of Agriculture (in Thai language). 


\title{
NHẬN DẠNG HÌNH THÁI VÀ BƯớC ĐẦU PHÂN LOẠI MỘT SỐ GIỐNG SĂN (Manihot esculenta Crantz) Ở VIẸT NAM
}

\author{
Chu Đức Hà ${ }^{1}$, Lê Thị Ngọc Quỳnh ${ }^{1}$, Nguyễn Trọng Hiển ${ }^{2}$, Phạm Thị Lý Thu ${ }^{1}$, \\ Lê Huy Hàm ${ }^{1}$, Lê Tiến Dũng ${ }^{1}$ \\ ${ }^{1}$ Phòng Thí nghiệm Quốc tế Chọn giống Phân tử Sắn, Viện Di truyền Nông nghiệp \\ ${ }^{2}$ Trung tâm Nghiên cứu và Phát triển Cây có củ, Viện Cây lương thực
}

\section{TÓM TẮT}

Nghiên cứu này được tiến hành để thiết lập cơ sở dữ liệu về hình thái cây sắn (Manihot esculenta Crantz) ở Việt Nam. Kết quả đã xác định được 20 đặc điểm hình thái đặc trưng, có thể thu thập theo từng giai đoạn. Trong đó, có 4 chỉ tiêu liên quan đến lá trưởng thành, 2 chỉ tiêu trên cuống lá có thể quan sát ở giai đoạn từ 4 tháng sau khi trồng. trong khi có 12 đặc điểm hình thái trên thân, củ ở giai đoạn sau 8 tháng và giai đoạn thu hoạch. Hai chỉ tiêu trên lá đỉnh có thể quan sát ở bất cứ giai đoạn sinh trưởng nào của cây sắn. Từ đó, chúng tôi đã bước đầu xây dựng được cây phân loại cho 7 giống sắn phổ biến tại Việt Nam dựa trên 6 đặc điểm hình thái đặc trưng. Giống sắn KM 140 có lá đỉnh màu đỏ tía, trong khi KM 98-7 có thể phân biệt bằng hình thái thùy trung tâm dạng thẳng hẹp. Cuống lá gắn lên thân không có quy luật là đặc điểm đặc thù của giống địa phương XVP, trong khi lồi sẹo lá của SM 937-26 có kích thước trung bình. Ba giống KM 419, KM 98-5, và KM 94 phân biệt nhau ở màu sắc lớp bên trong vỏ thân. Nghiên cứu này sẽ được tiếp tục phát triển nhằm nhận dạng đẩy đủ hình thái của các giống sắn Việt Nam.

Tù khóa: Manihot esculenta, cây sắn, giai đoạn sinh trưởng, hình thái, nhận dạng.

Received 27 July 2016, accepted 20 September 2016 